\title{
2. Philanthropic and impact investors: private sector engagement, hybridity and the problem of definition
}

\section{Prachi Srivastava and Robyn Read}

\section{PURPOSE}

Private sector engagement in education is typically conceptualised as the provision of education or education services by non-state private actors. It is, however, broader than this and tends to occur in four main areas, that is, the provision, financing, management and regulation of education, and increasingly, of ancillary education services by non-state private actors. They may work with varying degrees of independence from government/ public and/or other private/non-state actors. Non-state private actors in global education may be said to operate along a continuum of three main statuses. These include profit-oriented or commercially driven entities, of which some may be publicly listed while others may be privately held (Fielden \& LaRocque, 2008). Others are oriented towards making a positive social impact without profit (e.g., may be registered as trusts or charities in their local contexts). Hybrid actors sit between the two, having both a profit and social impact motive.

Alongside the growth in the number and range of non-state private actors in global education, is a diversification of investment strategies (Bhanji, 2008; D. Capital Partners, 2013; Steer, Gillard, Gustafsson-Wright \& Latham, 2015). Investors are increasingly orienting towards social impact and blended value investment strategies, resulting in intensified interest in hybrid actors and strategies. The range of such actors includes some with close connections to business and to corporate entities. Examples of non-state private actors considered to be hybrid or using hybrid strategies in education include: private foundations (e.g., independent, family, corporate and privately funded community foundations); corporate social responsibility (CSR) units; social innovation funders; impact investors; social enterprise organisations, etc.

Within this group, our interest was on private foundations and impact 
investors as financers in/of education. Our research shows that dichotomised conceptualisations of private foundations as 'pure-type' philanthropic actors, and of social impact and blended value investment as the exclusive purview of private-sector impact investors, are unhelpful and inaccurate. They do not consider the multiplicity of strategies such actors use or the forms through which they organise their work - in short, they do not account for the very nature of hybridity.

This is aggravated by the lack of consensus on terminology and definitions in the existing literature, posing significant challenges to conducting research (Marten \& Witte, 2008; Steer et al., 2015; United Nations Economic and Social Council [ECOSOC], 2012; Thornley et al., 2016). Conceptual gaps can lead to data inaccuracies, which are likely to persist without a typological framework (Höchstädter \& Scheck, 2015). This can have serious consequences in assessing the impact of specific types of actors in a number of areas, including accurately estimating their contributions to filling education funding gaps.

However, constructing a framework that is useful in categorising different types of organisations, yet is flexible to account for hybridity, is no easy task. This chapter provides a first step towards filling some of these conceptual gaps. It presents insights from background conceptualisations framing a larger regional-level project mapping the target geographies, education sector priorities and education initiatives of non-state private actors in education in South Asia and East Asia and the Pacific. ${ }^{1}$ A sample of non-state private actors was extracted from five regional and global sources to develop a pilot database of active funders/investors in education in Asia. ${ }^{2}$ Publicly accessible data were gathered on private foundations and impact investors in the sample. This empirical pursuit revealed serious definitional inconsistencies in the conceptual literature and in how terms are used and understood by organisations themselves.

First, the chapter considers the implications of hybridity on definitional exercises. This is followed by a discussion on methods employed. The bulk of the chapter focuses on two contributions: (1) pre-determined definitions of philanthropic and hybrid actors revealed in the conceptual work and (2) an inductively derived working typology on organisational forms. We developed the latter by drawing out characteristics from organisations in the database and progressively matching them against pre-determined

\footnotetext{
1 Operationalised using the World Bank typology of regions and countries.

2 Organisations were extracted from: Asian Venture Philanthropy Network membership database, Center for Education Innovations programs database (tracing initiatives to funders), Forbes Asia's 2017 Heroes of Philanthropy List (tracing individuals to philanthropic organisations), Global Impact Investing Network members list and The Asia Foundation donor list.
} 
definitions. We contend that inductive characterisations are better-suited to respond to the demands of hybridity in classifying organisational forms.

\section{BUILDING A CASE FOR ORGANISATIONAL SPECIFICATION IN THE CONTEXT OF HYBRIDITY}

Given the range of data gaps, the development of a typology may seem less urgent than empirical analyses. For example, literature reviews informing this project revealed significant lacunae in: (1) scope of activities, range of actors and the relationships between them, magnitude and types of investment and sub-sectors of engagement (Daggers \& Nicholls, 2016; Marten \& Witte, 2008; Schölmerich, 2012; ECOSOC, 2012; van Fleet, 2012); (2) the contribution of Southern actors operating regionally and domestically (ECOSOC, 2012; Right to Education Project, 2015; Srivastava \& Oh, 2010); (3) in-depth analyses on regions in the Global South (Srivastava \& Oh, 2010); (4) systematically reported or shared data; (5) and comprehensive data gathering and tools to track and evaluate the evolution of private sector engagement in education (Moumné \& Saudemont, 2015), including shared platforms for data collection and analysis (ECOSOC, 2012).

The disparate nature of the literature and scarcity of data, particularly on hybrid actors and forms of engagement, has led some researchers to conclude that focusing on empirical questions might be more fruitful (Dacin, Dacin \& Matear, 2010). However, deficiencies in specification of terms obscure empirical analysis. Operationally, complications arise from the lack of accepted terminology on organisational forms and further inaccuracies on investment strategies and profit statuses. Without specification, one cannot, for example, compile data on which types of organisations finance education initiatives in the aggregate (or comparatively), where or to what magnitude. This is further aggravated in regional or comparative research, as regulatory frameworks governing non-state actors vary across countries - what may 'count' as a particular organisational form in one context may not in another.

Concurrently, there are emerging analyses on complex institutional processes, partnerships and networks through which a range of philanthropic and other non-state (and state) actors engage in education globally, some with competing motivations and interests (Ball \& Olmedo, 2011; Menashy, 2016; Srivastava \& Baur, 2016; Verger, 2012). These run alongside an increased focus on 'strategic impact' and social and blended value investment strategies (i.e., seeking financial and social return) (D. Capital Partners, 2013; Steer et al., 2015), of which arguably, impact investment is at the forefront. Impact investment is defined by the Global Impact 
Investing Network (GIIN) as: 'investments made into companies, organizations, and funds with the intention to generate social and environmental impact alongside a financial return. Impact investments can be made in both emerging and developed markets, and target a range of returns from below market to market rate, depending on investors' strategic goals' (Global Impact Investing Network [GIIN], n.d.).

While impact investment is largely associated with newer hybrid actors, in fact, as a funding modality, it is not limited to specific organisational forms. Emerging data from this project show that philanthropic actors, for example, may employ impact investment as part of their portfolios. One example is the use of impact investment by the Michael \& Susan Dell Foundation (MSDF) in India. Through equity investments and loans, MSDF made impact investments in 27 initiatives in India at the time of writing, a number of which were in education. The range of supported initiatives was broad, including but not limited to, assessment systems for low-fee private schools, exam coaching centres and mobile education technology applications. ${ }^{3}$

Furthermore, the use of these and other strategies broadly encompassed as 'impact-oriented' or as 'social entrepreneurship/innovation' is not limited to non-state private actors. For example, Jing and Gong (2012) provide a detailed account of the Shanghai Municipal Bureau of Civil Affairs' annual venture philanthropy programme, a government-led venture supporting service organisations for children and youth, among other target groups. The CDC, the UK's development finance institution, wholly owned by the UK's Department for International Development (DFID), established the Impact Fund. The Impact Fund invests 'DFID's long term, "patient" capital in impact investment funds that invest in enterprises which serve the poor as consumers, suppliers or employees' (Impact Programme, 2018). It is targeted to low-income and lower middle-income countries in Sub-Saharan Africa and South Asia and includes investments in a number of sectors, including education.

These examples speak to the central premise of hybridity, or more precisely, 'hybrid organizing', defined by Battilana and Lee (2014) as: 'the activities, structures, processes and meanings by which organizations make sense of and combine aspects of multiple organizational forms' (p. 398). They further suggest considering hybridity as the combination of: (1) multiple organisational identities; (2) multiple organisational forms; and (3) multiple institutional logics (Battilana \& Lee, 2014). As multiplicity

\footnotetext{
3 MSDF also made impact investments in the United States. These are not discussed here given the focus of our study was Asia. Data from Michael \& Susan Dell Foundation (n.d.) accurate as of 10 September 2018.
} 
is inherent to hybridity, it is necessary to explicate the specifics of the hybrid, otherwise, discerning how organisations operate and their underlying strategies will be difficult. Doing so, however, necessitates a flexible approach.

Of the three dimensions highlighted above, the focus of our analysis was on defining organisational identities to determine organisational forms. We intended to come to an operational agreement for empirical data collection for the database. Our approach first relied on reviewing the literature to find suitable terms, which we then tested on a sub-sample of organisations from the larger database. However, the very nature of hybridity and the complexity of organisational processes and structures; opacity of organisational data; conflation of terms and disparate literature presented some problems. Thus, we later inductively applied pre-determined definitions to self-reported organisational characteristics in order to refine operational definitions and construct a working typology for analysis.

\section{METHODS}

The first phase of conceptualisation involved merging two literature reviews. The first broad review was on private sector engagement in education in the Global South conducted for a separate study. While larger in scope, that review was critical in directing the second, focused review and formed the basis for broad categorisations and range of actors. The second review was on specific organisational forms of philanthropic and other actors relevant to the study. We tested terms from both reviews, first on a sub-sample of organisations extracted from the Asian Venture Philanthropy Network (AVPN), a regional network service organisation used to extract sample organisations for the database. Relatively early on, it became clear that pre-determined definitions were insufficient. This was particularly true for newer hybrid forms. Thus, we refined pre-determined definitions using an inductive approach (see Thomas [2006] for a useful review) on the full sample of organisations in the database (see section entitled 'Testing pre-determined definitions and inductive categorisation').

\section{Review 1: Private Sector Engagement (Broad Review)}

A total of 246 individual search strings using combinations of 24 keywords/terms related to private sector engagement and various non-state actors in the Global South were employed. A time limitation was added (2005 to 2015, and later updated to 2017) to capture the most current literature. Google Scholar was used to maximise collecting working 
papers, reports and other grey literature from international agencies and private sector organisations that may otherwise be excluded, in addition to scholarly work. The first 10 pages of results (15, for very large results) were examined. In total, 250 resources were collected, examined and considered.

Abstracts were read and copied in a master document for the next step of screening. Duplicate results were removed. Screening at this stage removed material already in Srivastava's existing literature database. Remaining resources were reviewed, and any that were not directly related to areas of interest, were eliminated. Culled results were reviewed a second time more thoroughly, uploaded in Mendeley bibliographic reference manager and attributed content-specific keywords. Each reference was then read and annotated.

\section{Review 2: Philanthropic and Hybrid Organisational Forms (Focused Review)}

The second review focused on literature related to the search terms (social+) impact invest* and (venture +) philanthrop*, given the focus of this study. The search sought to identify pre-existing typologies and operationalisable definitions of organisational forms, to complement Review 1. Similar screening and review processes were employed as above. A preliminary search in ERIC, the main academic education database, was conducted. Given the limited education literature in this area, the time period and academic fields for the search were extended to capture academic literature in the areas of business and international development using EBSCO, JSTOR and SCOPUS (time limitation 1997-2016). ${ }^{4}$

Given the acknowledged contributions of development and private sector organisations to literature in this area, a further targeted search was conducted to examine publications from the websites of 18 key organisations identified in the literature and by expert informants as thought leaders or key players in philanthropy and in impact investing. ${ }^{5}$ Working definitions for each organisational form were developed by combining the search results from this focused review with identified definitions from the larger review (Table 2.1 to be further discussed in 'Disentangling private

4 No relevant literature was found prior to 1997. Following the results of the focused review (Review 2) at the end of 2016, we returned to Review 1 in early 2017 to double-check that there were no missing sources.

5 These are: AVPN, Bellagio Initiative, Bill \& Melinda Gates Foundation, Brookings Institution, Consultative Group to Assist the Poor, GIIN, Ford Foundation, Foundation Center, Goldman Sachs, International Finance Corporation, MasterCard Foundation, OECD, Omidyar Network, Rockefeller Foundation, UNDP Istanbul International Center for Private Sector in Development (IICPSD), World Bank and World Economic Forum. 


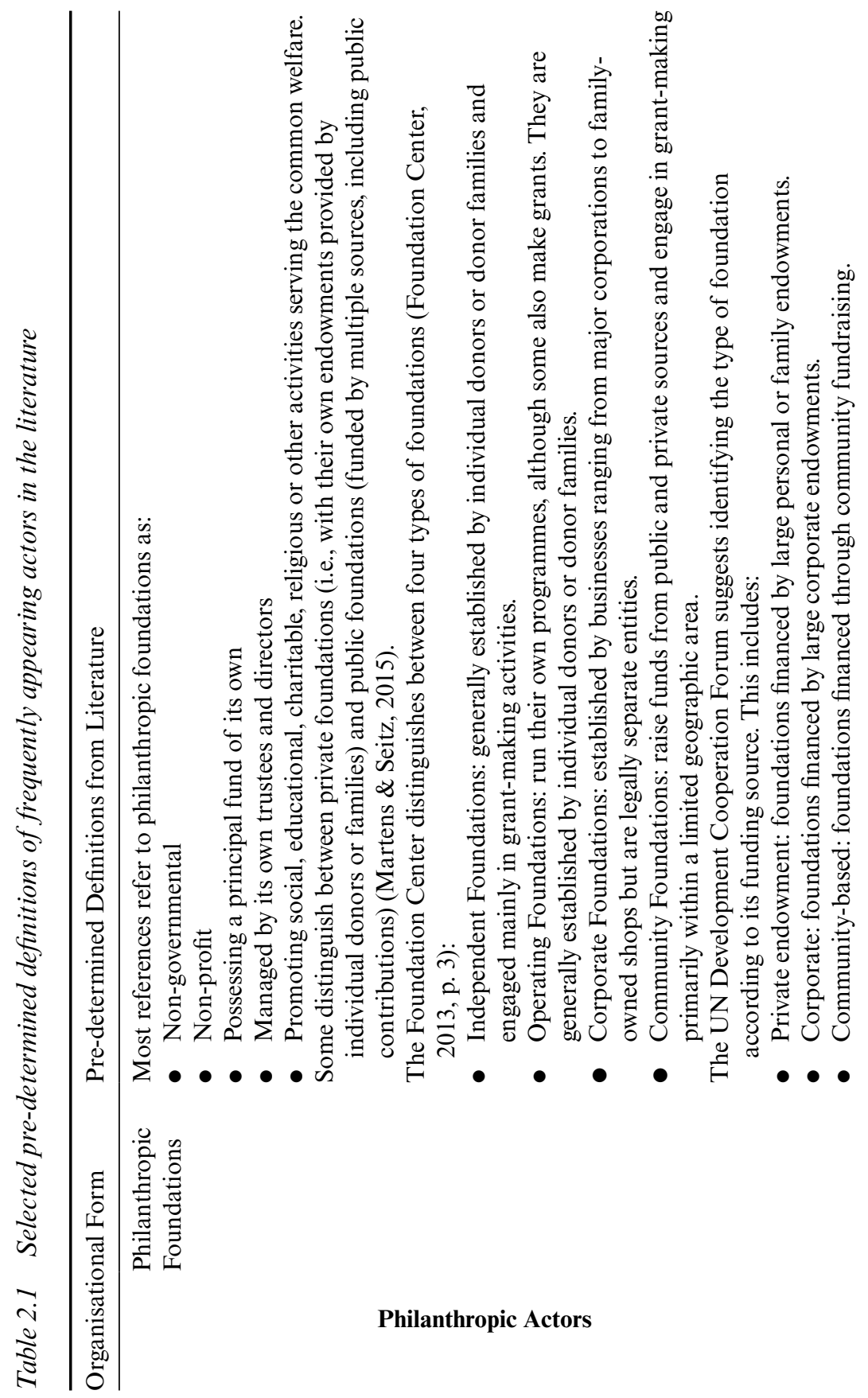




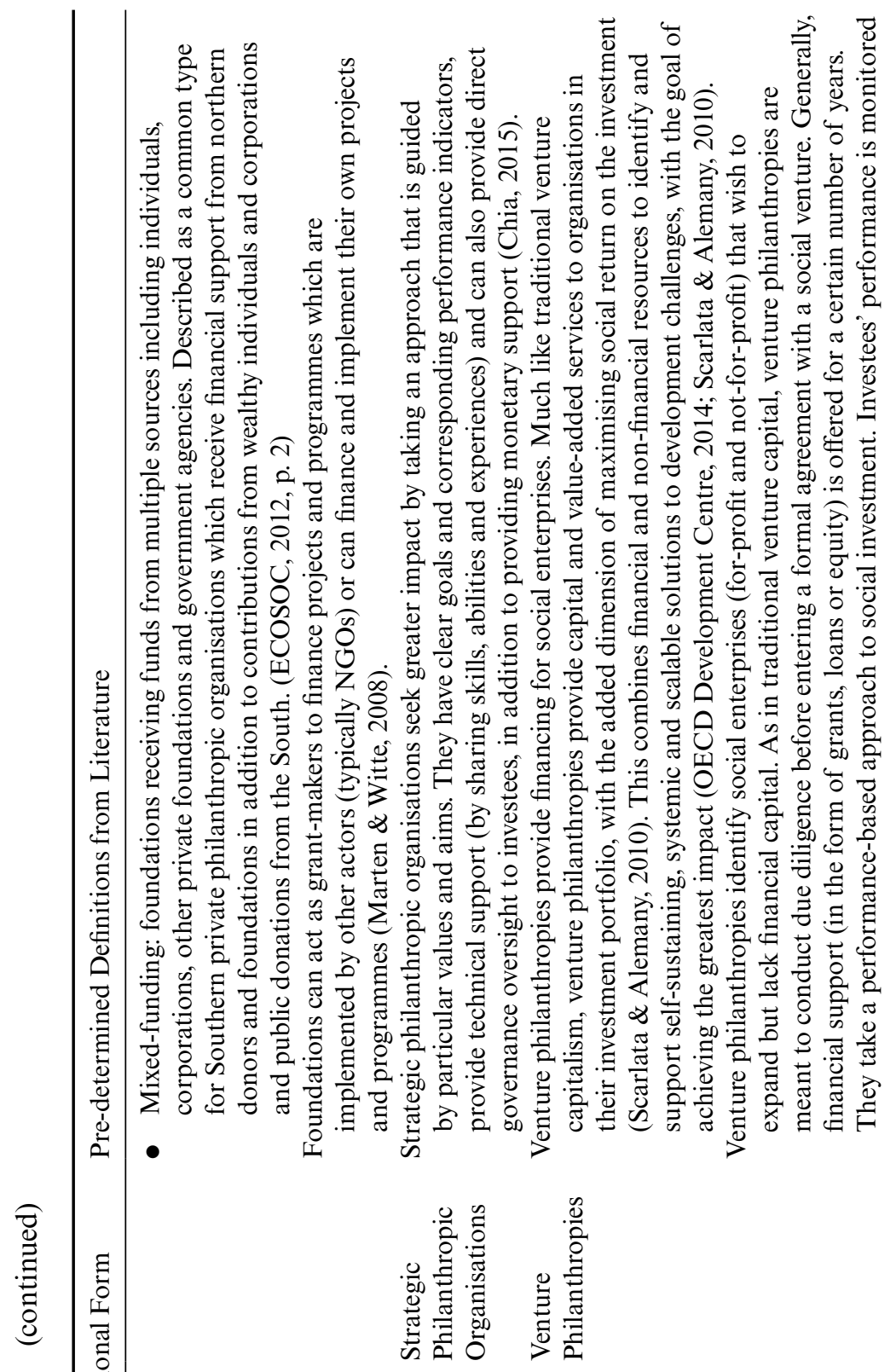

Philanthropic Actors 


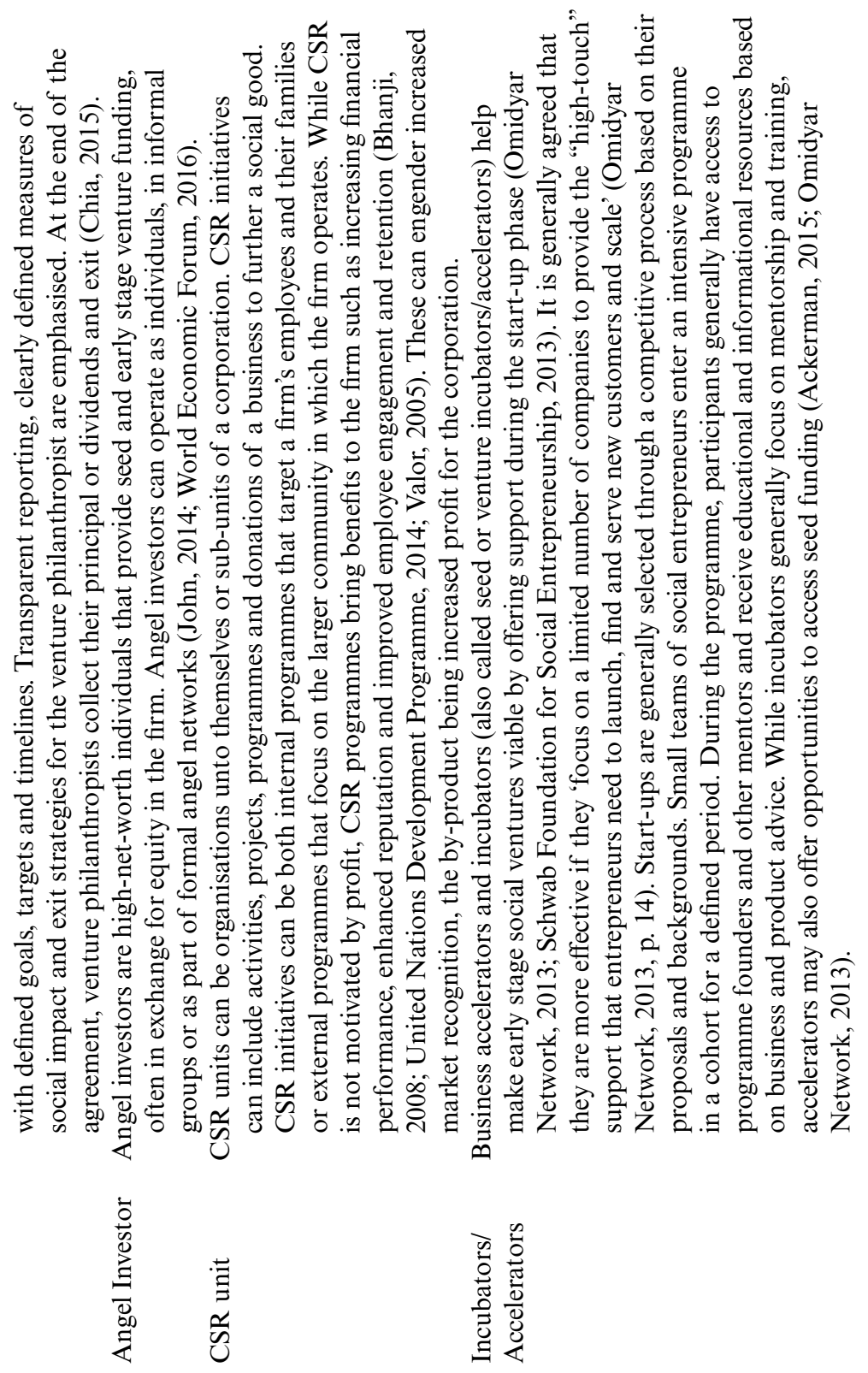

Other Relevant Actors 


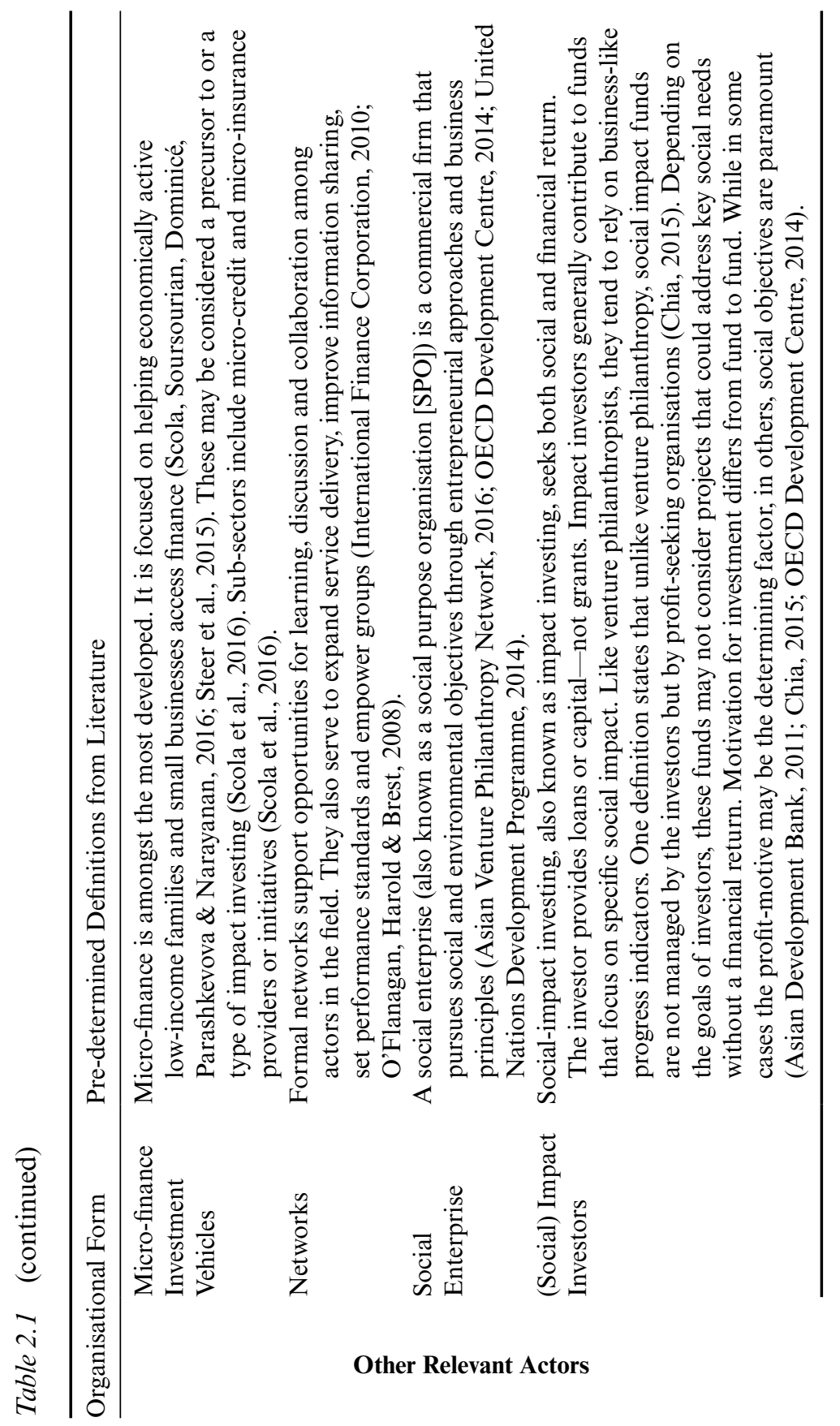


sector hybridity'). These were tested on a sub-sample of relevant organisations extracted for the database discussed immediately below.

\section{Testing Pre-determined Definitions and Inductive Categorisation}

A working typology for organisational forms was developed based on the literature reviews above. This was tested using AVPN's publicly accessible list of member organisations. A sub-sample of 87 organisations operating in education was extracted. Websites for each organisation were consulted to classify organisational form according to pre-determined definitions from the literature (Table 2.1).

Initially, this was done by organisational self-identification. In some cases, the identifications were explicit, in others they were determined by aligning the organisation's mission and status with pre-determined definitions. This was done by gathering further data on the vision, mission, portfolio, legal status and financial information, where available. As with the full sample and throughout the study, this process was highly dependent on the level of detail and documentation with which organisations publicly reported their operations. It was clear, early in this exercise, that pre-determined definitions were insufficient. These difficulties were partly due to a lack of clear and transparent organisational-level data, and partly, because the conglomeration of actors did not fit neatly into existing categories.

As the full sample for the database was compiled, inductive categorisation was used to classify organisational form and to develop a working typology. In simple terms, 'inductive analysis refers to approaches that primarily use detailed readings of raw data to derive concepts, themes, or a model through interpretations made from the raw data by an evaluator or researcher' (Thomas, 2006, p. 238). We extracted relevant data from organisational websites as above, but rather than shoehorning them into the pre-existing categories, we sought commonalities across them and developed new groupings emerging from the data. This consisted of developing criteria for inclusion and descriptive definitions by iterating between organisational self-identification data and the pre-determined definitions, refining and revising the latter to more accurately represent the organisational forms of actors in the sample. The result is presented in Table 2.2. As hybridity is inherently dynamic, we do not take a static view of the resulting definitions in the working typology. As analysis of the database evolves, we expect to make further refinements. 


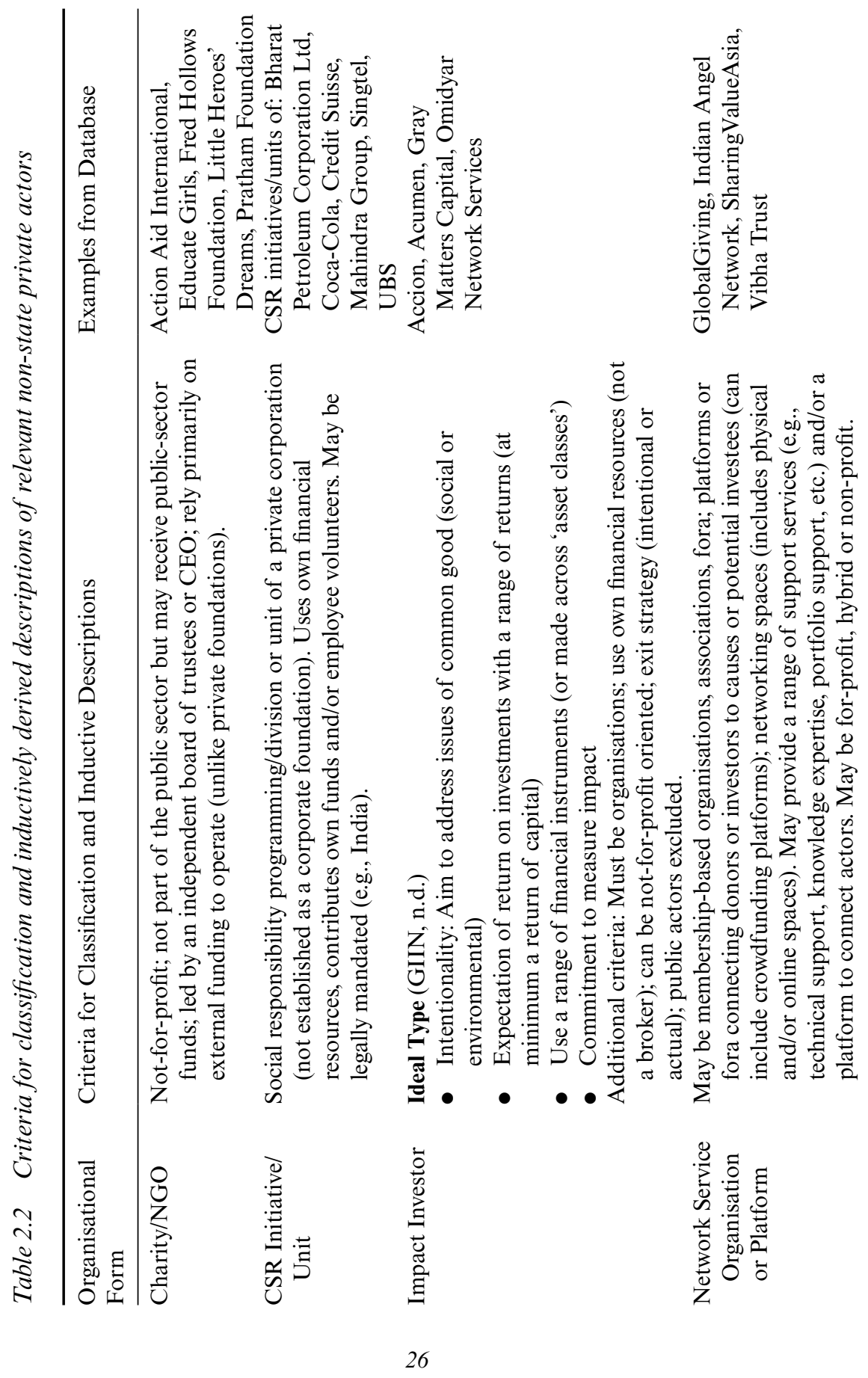



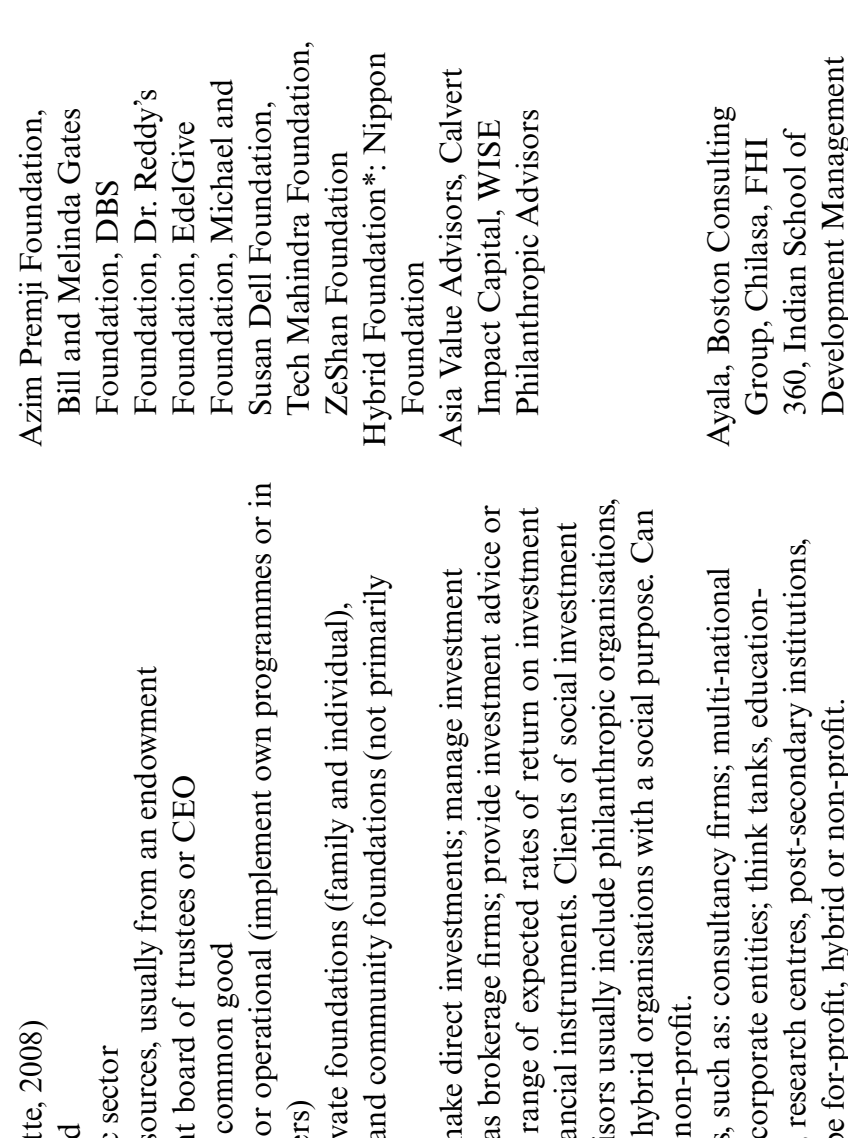

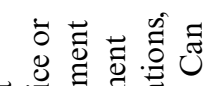

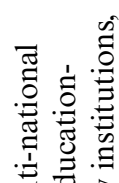

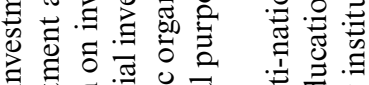

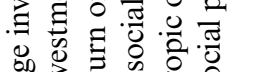

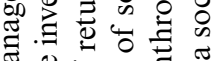

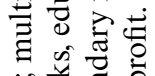

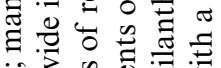

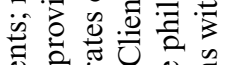

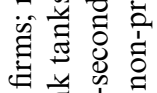

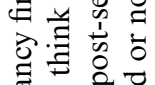

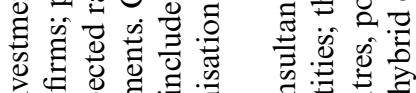

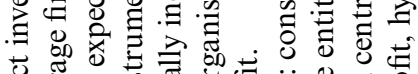

ᄋे

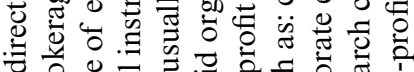

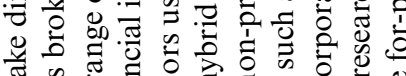

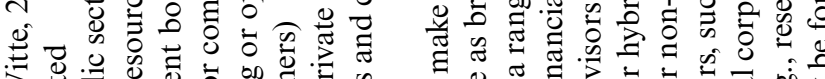

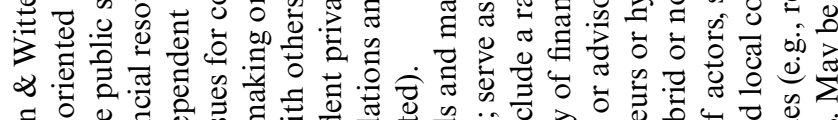
లี

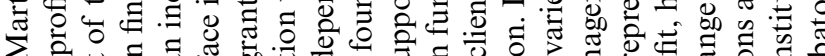

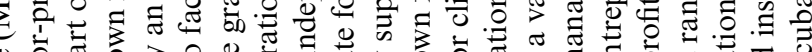
휴

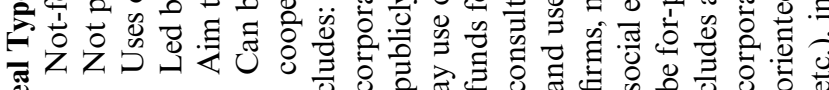

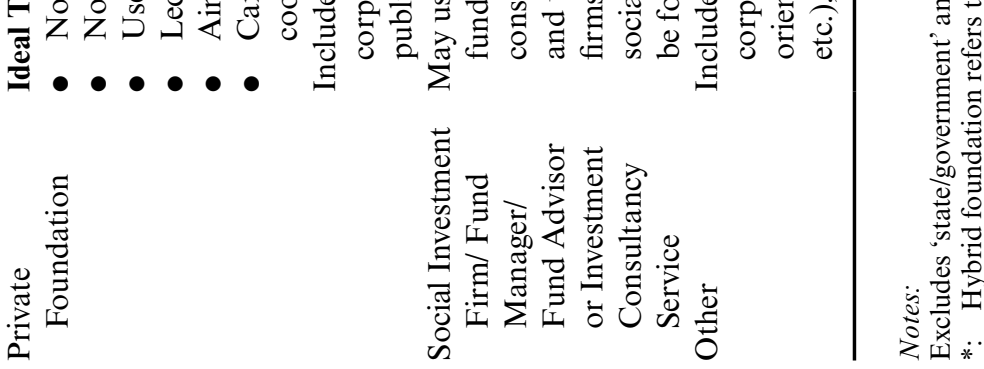




\section{DISENTANGLING PRIVATE SECTOR HYBRIDITY? LOCATING ORGANISATIONAL FORMS IN THE LITERATURE}

Table 2.1 presents selected pre-determined definitions of the philanthropic and hybrid organisational forms that appeared most frequently in our reviews of the literature (Review 1 and Review 2 above). Given the complications outlined thus far and the analysis below, we do not imply that these definitions are authoritative, exhaustive, or free of contestation. They were selected, in the first instance, to provide guidance on operationalising organisations for this study, and later reframed inductively by drawing data from sample organisations.

As is clear from Table 2.1, explicating organisational forms is difficult and problematic. First, there are multiple organisational forms and multiple sources and definitions, sometimes for the same form. Some variations in definition are slight, but others are quite significant. Some may even have legal distinctions in a specific context. These variations may make it impossible to decipher the most appropriate 'standard' definition for an organisational form in the absence of specific regulatory or procedural contexts. Such issues are starkly apparent in the case of 'philanthropic foundations'.

Second, some terms may be commonly referred to or understood as strategies and organisational forms, e.g., strategic or venture philanthropy. This blurs the organisational identities, organisational forms and institutional logics of hybrid organising (Battilana \& Lee, 2014). Third, certain characteristics suggested by a definition may not correspond to all organisations that operate as such. For example, a characteristic of impact investment funds in one definition was: 'social impact funds are not managed by the investors themselves, but rather by profit-seeking organizations' (Chia, 2015, p. 10). However, there are examples of organisations identifying as impact investors that also manage social impact funds themselves, and some of them are not profit-seeking. Fourth, some may be thought of more commonly as individuals (e.g., angel investors) or may operate informally or as groups through other organising bodies (e.g., network service organisations).

Finally, there is a further attempt in the literature to classify actors by profit motive. The three most typical classifications are: (1) for-profit (or motivated by profit); (2) not-for-profit (or motivated solely by social impact); and (3) hybrid or blended, motivated by profit and social impact (OECD Development Centre, 2014; Steer et al., 2015; Thornley et al., 2016). Traditionally, defining for-profit and non-profit actors involves ascertaining whether shareholders/owners draw profit out as dividends or 
whether shareholders/owners reinvest gains in the operation (and to what extent or for what purpose). While this distinction may seem relatively straightforward, it is often difficult to ascertain in practice, even in the case of philanthropic or other charitable organisations (Au \& Lubienski, 2016; Olmedo, 2016).

Olmedo (2016) takes the example of an organisation in England that may be registered both as a charity and a 'company limited by guarantee', commonly referred to as a 'charitable company'. Such an organisation may own property and gain profit, but it must be reinvested in the organisation. He points out, however, that the purposes of reinvestment may not be defined. Thus, it 'does not exclude the alternative possibility of using their economic assets to trade and purchase services and goods' (Olmedo, 2016, p. 48), in lieu of reinvesting gains for the purposes of funding/implementing initiatives.

The data collection process for this project found that reporting on the mechanics, amounts and strategies of reinvesting projected gains on investments was opaque. This is particularly important to ascertain for actors officially classified as 'non-profit' (e.g., similar to 501(c) status in the United States), and who may simultaneously employ strategies seeking some financial return (e.g., impact investment). Similarly, there is an assumed continuum of economic returns on investment (i.e., above 5 per cent, 10 per cent, 15-20 per cent, etc.) along with social impact for hybrid or blended organisations. However, there is no consensus on the maximum threshold for economic returns beyond which investments/actors would be considered profit-oriented instead of hybrid.

\section{AN ALTERNATIVE CLASSIFICATION: TOWARDS AN INDUCTIVE WORKING TYPOLOGY}

Applying pre-determined definitions to organisations in the sample proved difficult. First, the sum of sample organisations did not correspond to those uncovered in the reviews. In some cases, they comprised other forms (e.g., charities and non-governmental organisations [NGOs], social investment funds/managers/advisory services) that required explication. In others, there were too few to warrant separate categorisation (e.g., accelerators and incubators). Second, in many instances, publicly available organisational data did not specify or provide sufficient detail on organisational operations required to match them to pre-determined definitions. In such instances, organisational forms were difficult to discern using external criteria. Third, different organisations operating similarly did not necessarily identify themselves in the same way. For example, one 
organisation may frame itself as a seed funder, while another organisation operating similarly (and providing seed funding) may identify itself as an impact investor. In these cases, we had to examine self-descriptions more closely and adapt pre-determined definitions to make them more broadly applicable. Finally, the lines between organisational forms and investment strategies can be blurry and inconsistently applied by organisations themselves. For example, a corporation's CSR initiative could be directly implemented, set up as a unit within the company or linked to the parent corporation but take the form of a corporate foundation. Furthermore, there may be no additional confirmatory data. In such cases, it was impossible to apply a static definition. These examples from our initial attempts at categorisation led us to reassess whether classifying organisations according to pre-determined definitions is useful or possible.

As a result, we developed a working typology (see Table 2.2 with examples from the data). Given the focus for this study, private foundations and impact investors were the most relevant forms, in addition to the following that were found to be the most prevalent in the sample: charity/NGO, CSR initiative/unit, network service organisation or platform, social investment firm/fund manager/fund advisor or investment consultancy service and other, incorporating a range of actors.

As far as possible, we attempted to inductively extract relevant criteria emerging from organisational-level data that could be applied across a variety of regulatory contexts. We deciphered characteristics of organisational forms by matching self-identification organisational data progressively against pre-determined definitions, instead of relying on regulatory compulsions that would apply only to a particular class of organisations in a specific domestic context. This was necessary because of the centrality of hybridity, but also to categorise actors that could later be aggregated and compared for this multi-country study. For example, in some countries in Asia, there is no formal distinction for a private foundation (e.g., India, Vietnam), whereas, in others there is (e.g., China, Indonesia, Japan). ${ }^{6}$ Thus, extracting relevant organisational characteristics and adapting existing definitions was more useful for comparative analysis.

The working typology was useful in enabling a level of classification without which the sample could not be analysed. But, this was messy. A number of examples speak to the hybridity of institutional logics prevalent in this field of study, and that contributed to experienced difficulties. In these cases, we reverted to the main aims of the study to proceed.

6 Based on the Council on Foundations Country Notes for China, India, Indonesia, Japan and Vietnam. Retrieved from https://www.cof.org/program-initiative/country-notes on 10 September 2018. 
For example, since the focus of the project was on the private sector, public-sector actors were deliberately excluded from the working typology. We do not imply that public-sector actors cannot fall into some of the inductively derived classifications (but for their public status) or that they do not use some funding strategies similar to those of non-state private actors. Government agencies, like DFID as mentioned above, may be considered impact investors if they meet the four main criteria in Table 2.2 (i.e., intentionality; expectation of return on investments; using a range of financial instruments; commitment to measure impact). There are also publicly funded charities and foundations. However, given the focus of the study, they were excluded.

There were also private foundations that simultaneously met the four main criteria for impact investors (e.g., MSDF). In these cases, the classification of 'private foundation' took precedence if they met the main criteria on the organisational structure of private foundations, particularly if grants disbursement was the primary funding modality. Finally, as mentioned, regulatory distinction for the designation of 'private foundation' does not exist across countries. Thus, there were private-sector actors calling themselves 'foundations' but functioning largely by receiving funds from other grant-making donors (e.g., Fred Hollows Foundation, Pratham). In these cases, their main funding source and management structure took precedence.

\section{CONCLUDING COMMENTS AND WAYS FORWARD?}

This chapter developed from the need to operationalise non-state private actors that are 'hybrid organising' for the empirical purposes of data collection for a study mapping the target geographies, education sector priorities, and initiatives of private foundations and impact investors operating in Asia. It was tempting to apply discrete pre-determined categories to simplify analysis. However, applying existing definitions proved to be counterproductive. We faced a number of difficulties related to the lack of clarity in the literature and insufficient publicly reported information on the actors and their operations. More substantively, there were also complexities related to the multiple organisational forms and strategies of actors in our sample. This is inherent to the nature of hybridity.

Hybrid organising necessitates embracing a multiplicity of organisational identities, forms and logics. However, embracing hybridity presents challenges. These are aggravated when organisational data are either inconsistent or not fully transparent, and further, when researching comparatively across very different regulatory contexts. 
Thus, we faced a conundrum. While a typology of organisational forms is necessary to push research forward, employing pre-determined definitions is not wholly appropriate. This led to the development of an inductively derived working typology that was specific to the aims of this study. The process centred on progressively refining existing definitions iteratively in line with organisational self-identification data to establish a more relevant framework. As hybridity intimates continuous evolution (OECD Development Centre, 2014), we submit that any categorisation must ultimately serve as a working typology, open to new types of actors and new definitions as the field develops. We argue towards adopting a flexible approach that can be inductively derived within a framework of characteristics (that are, ideally, observed), which should clearly articulate how particular organisational forms are defined within specific studies. While regulatory distinctions may exist for certain organisations in specific domestic contexts, they may be insufficient or inappropriate for comparative work.

\section{ACKNOWLEDGEMENTS}

This project was funded through a grant from the Social Sciences and Humanities Research Council of Canada (Principal Investigator, Srivastava), with co-funding from the Brookings Institution. Views do not reflect those of the funders. We are grateful to the reviewer for insightful comments that led to sharpening the chapter.

\section{REFERENCES}

Ackerman, X. (2015). Innovation and action in funding girls' education (Global Economy \& Development Working Paper No. 84). Washington, DC: Brookings Institution. Retrieved November 26, 2018, from http://www.brookings.edu/re search/papers/2015/03/innovation-action-funding-girls-education-ackerman

Asian Development Bank. (2011). Impact investors in Asia: Characteristics and preferences for investing in social enterprise in Asia and the Pacific. Manila, Philippines: Author. Retrieved November 26, 2018, from https://www.adb.org/ sites/default/files/publication/29306/impact-investors.pdf

Asian Venture Philanthropy Network. (2016). Annual report 2016. Singapore: Asian Venture Philanthropy Network. Retrieved November 26, 2018, from https://avpn.asia/wp-content/uploads/2016/09/annual-report-2016.pdf

$\mathrm{Au}, \mathrm{W} .$, \& Lubienski, C. (2016). The role of the Gates Foundation and the philanthropic sector in shaping the emerging education market: Lessons for the US on privatization of schools and education governance. In A. Verger, C. Lubienski, \& G. Steiner-Khamsi (Eds.), World yearbook of education 2016: The global education industry (pp. 27-43). Abingdon, UK: Routledge. 
Ball, S. J., \& Olmedo, A. (2011). Global social capitalism: Using enterprise to solve the problems of the world. Citizenship, Social and Economics Education, 10(2), 83-90.

Battilana, J., \& Lee, M. (2014). Advancing research on hybrid organizing: Insights from the study of social enterprises. The Academy of Management Annals, 8(1), 397-441. https://doi.org/10.1080/19416520.2014.893615

Bhanji, Z. (2008). Transnational corporations in education: Filling the governance gap through new social norms and market multilateralism?. Globalisation, Societies and Education, 6(1), 55-73.

Chia, A. (2015). Potential and prospects for philanthropy in implementing post-2015 development goals (ADB Sustainable Development Working Paper Series No. 38). Manila, Philippines: Asian Development Bank. Retrieved November 26, 2018, from https://www.adb.org/sites/default/files/publication/158689/sdwp-038. pdf

D. Capital Partners. (2013). Impact investing in education: An overview of the current landscape (Education Support Program Working Paper Series No. 59). New York, NY: Open Society Foundations. Retrieved November 26, 2018, from http://www. opensocietyfoundations.org/sites/default/files/impact-investing-education-overvi ew-current-landscape-20140106_0.pdf

Dacin, P. A., Dacin, M. T., \& Matear, M. (2010). Social entrepreneurship: Why we don't need a new theory and how we move forward from here. Academy of Management Perspectives, 24(3), 37-57. https://doi.org/10.5465/AMP.2010.52842950

Daggers, J., \& Nicholls, A. (2016). The landscape of social impact investment research: Trends and opportunities. Oxford, UK: Saïd Business School, University of Oxford. Retrieved June 27, 2019, from http://eureka.sbs.ox.ac.uk/7019/1/Land scape-of-social-impact-investment-research.pdf

Fielden, J., \& LaRocque, N. (2008). The evolving regulatory context for private education in emerging economies (Education Working Paper Series No. 14). Washington, DC: World Bank and International Finance Corporation. Retrieved June 27, 2019, from https://www.ifc.org/wps/wcm/connect/7db3ed804970b ff99a01da336b93d75f/Discussion\%2BPaper\%2BFinal.\%20pdf?MOD=AJPER ES

Foundation Center. (2013). Key facts on US foundations: Edition 2013. New York, NY: Author. Retrieved November 26, 2018, from https://www.issuelab.org/ resources/25145/25145.pdf

Global Impact Investing Network (GIIN). (n.d.). What you need to know about impact investing. Retrieved May 26, 2018, from https://thegiin.org/impact-inves ting/need-to-know/\#what-is-impact-investing

Höchstädter, A. K., \& Scheck, B. (2015). What's in a name: An analysis of impact investing understandings by academics and practitioners. Journal of Business Ethics, 132(2), 449-475. https://doi.org/10.1007/s10551-014-2327-0

Impact Programme. (2018). Impact Fund. London: UKAid Impact Fund. Retrieved June 27, 2019, from http://www.theimpactprogramme.org.uk/investmen ts-dfid-impact-fund/

International Finance Corporation. (2010). Strategic community investment: A good practice handbook for companies doing business in emerging markets. Washington, DC: Author. Retrieved November 26, 2018, from http://www.ifc. org/wps/wcm/connect/f1c0538048865842b50ef76a6515bb18/12014complete-web. pdf?MOD=AJPERES

Jing, Y., \& Gong, T. (2012). Managed social innovation: The case of government- 
sponsored venture philanthropy in Shanghai. Australian Journal of Public Administration, 71(2), 233-245. https://doi.org/10.1111/j.1467-8500.2012.00767.x

John, R. (2014). Virtuous circles: New expressions of collective philanthropy in Asia (Entrepreneurial Social Finance in Asia No. 3). Singapore: Asia Centre for Social Entrepreneurship and Philanthropy, NUS Business School.

Marten, R., \& Witte, J. M. (2008). Transforming development: The role of philanthropic foundations in international development cooperation (GPPi Research Paper Series No. 10). Berlin, Germany: Global Public Policy Institute.

Martens, J., \& Seitz, K. (2015). Philanthropic power and development: Who shapes the agenda? Aachen, Berlin, and Bonn, Germany: Bischöfliches Hilfswerk MISEREOR; Evangelisches Werk für Diakonie und Entwicklung Brot für die Welt - Evangelischer Entwicklungsdienst and Global Policy Forum. Retrieved November 26, 2018, from https://www.globalpolicy.org/component/content/arti cle/270-general/52829-philanthropic-power-and-development-who-shapes-the-ag enda.html

Menashy, F. (2016). Private authority or ambiguity? The evolving role of corporations and foundations in the Global Partnership for Education. In A. Verger, C. Lubienski, \& G. Steiner-Khamsi (Eds.), World yearbook of education 2016: The global education industry (pp. 63-77). Abingdon, UK: Routledge.

Michael \& Susan Dell Foundation. (n.d.). Funding. Retrieved September 10, 2018, from https://www.msdf.org/funding/\#!/impact_investing/India

Moumné, R., \& Saudemont, C. (2015). Overview of the role of private providers in education in light of the existing international legal framework. Investments in private education: Undermining or contributing to the full development of the human right to education? (UNESCO Working Papers on Education Policy $\mathrm{N}^{\circ} 1$ ). Paris, France: UNESCO. Retrieved June 27, 2019, from http://unesdoc.unesco.org/ima ges/0024/002438/243823e.pdf

OECD Development Centre. (2014). Venture philanthropy in development: Dynamics, challenges and lessons in the search for greater impact. Paris, France: Author. Retrieved November 26, 2018, from https://www.oecd.org/dev/Venture\%20Philan thropy $\% 20$ in $\% 20$ Development-BAT-24022014-indd5\%2011\%20mars.pdf.

O'Flanagan, M., Harold, J., \& Brest, P. (2008). The nonprofit marketplace: Bridging the information gap in philanthropy. Menlo Park, CA and New York, NY: The William and Flora Hewlett Foundation and McKinsey \& Co. Retrieved November 26, 2018, from https://www.hewlett.org/wp-content/uploads/2016/08/ whitepaper.pdf

Olmedo, A. (2016). Philanthropic governance: Charitable companies, the commercialization of education and that thing called 'democracy'. In A. Verger, C. Lubienski, \& G. Steiner-Khamsi (Eds.), World yearbook of education 2016: The global education industry (pp.44-62). Abingdon, UK: Routledge.

Omidyar Network. (2013). Accelerating entrepreneurship in Africa: Understanding Africa's challenges to creating opportunity-driven entrepreneurship. Redwood City, CA: Author.

Right to Education Project. (2015). The UK's support of the growth of private education through its development aid: Questioning its responsibilities as regards its human rights extraterritorial obligations (Alternative report presented to the Committee on the Right of the Child (CRC) on the occasion of the consideration of the list of issues related to the fifth periodic report of the United Kingdom of Great Britain and Northern Ireland (UK) during the 72nd session of the Committee). Retrieved November 26, 2018, from http://www.right-to-education.org/sites/right-to-educa 
tion.org/files/resource-attachments/RTE_Alternative_Report_CRC_ETO_UK_ FINAL_October_2015.pdf

Scarlata, M., \& Alemany, L. (2010). Deal structuring in philanthropic venture capital investments: Financing instrument, valuation and covenants. Journal of Business Ethics, 95(S2), 121-145. https://doi.org/10.1007/s10551-011-0851-8

Schölmerich, M. J. (2012). On the impact of corporate social responsibility on poverty in Cambodia in the light of Sen's capability approach. Asian Journal of Business Ethics, 2(1), 1-33. https://doi.org/10.1007/s13520-012-0016-6

Schwab Foundation for Social Entrepreneurship. (2013). Breaking the binary: Policy guide to scaling social innovation. Geneva, Switzerland: Schwab Foundation for Social Entrepreneurship and the World Economic Forum. Retrieved November 26, 2018, from http://www3.weforum.org/docs/WEF_Breaking_Binary_Policy_ Guide_Scaling_Social_Innovation_2013_2604.pdf

Scola, B., Soursourian, M., Dominicé, R., Parashkevova, M., \& Narayanan, R. (2016). Microfinance funds 10 years of research \& practice: A review of CGAP \& Symbiotics' microfinance investment vehicles surveys. Geneva, Switzerland and Washington, DC: Symbiotics and CGAP. Retrieved November 26, 2018, from http://symbioticsgroup.com/wp-content/uploads/2016/11/201612-Symbiotics_10y MIV_whitepaper.pdf

Srivastava, P., \& Baur, L. (2016). New global philanthropy and philanthropic governance in education in a post-2015 world. In K. Mundy, A. Green, R. Lingard, \& A. Verger (Eds.), The handbook of global education policy (pp.433-448). West Sussex, UK: Wiley-Blackwell.

Srivastava, P., \& Oh, S.-A. (2010). Private foundations, philanthropy, and partnership in education and development: Mapping the terrain. In S. L. Robertson, K. Mundy, A. Verger, \& F. Menashy (Eds.), Public private partnerships in education: New actors and modes of governance in a globalizing world (pp.460-471). Cheltenham, UK and Northampton, MA: Edward Elgar Publishing. Retrieved June 27, 2019, from https://www.elgaronline.com/abstract/9780857930682.00015.xml

Steer, L., Gillard, J., Gustafsson-Wright, E., \& Latham, M. (2015). Non-state actors in education in developing countries: A framing paper: Draft for discussion presented at the Annual Research Symposium of the Center for Universal Education. Washington, DC: Centre for Universal Education, Brookings Institution.

Thornley, B., Clark, C., Leijonhufvud, C., Arnoldy, A., Locascio, B., \& Dougherty, A. (2016). Navigating impact investing: The opportunity in impact classes. New York, NY: Tideline. Retrieved November 26, 2018, from http://tideline.com/wpcontent/uploads/Tideline_Navigating_Impact_Investing_Working_Paper.pdf? utm_source=site\&utm_medium=download\&utm_campaign=downloads

Thomas, D. (2006). A general inductive approach for analyzing qualitative evaluation data. American Journal of Evaluation, 27(2), 237-246. https://doi.org/10.1177/1098 214005283748

United Nations Development Programme. (2014). Barriers and opportunities at the base of the pyramid: The role of the private sector in inclusive development. Istanbul, Turkey: United Nations Development Programme, Istanbul International Center for Private Sector in Development. Retrieved November 26, 2018, from http://www.iicpsd.undp.org/content/istanbul/en/home/library/reports/ barriers-and-opportunities-at-the-base-of-the-pyramid---the-role/

United Nations Economic and Social Council. (2012). UN special policy dialogue on 'Private philanthropic organizations in international development cooperation: New opportunities and specific challenges'. Issues note. Development Cooperation 
Forum Special Dialogue. 27 February 2012. Retrieved November 26, 2018, from. https://www.un.org/en/ecosoc/newfunct/pdf/dcf_philanthropy_issues_note.pdf

Valor, C. (2005). Corporate social responsibility and corporate citizenship: Towards corporate accountability. Business and Society, 110(2), 191-212. https://doi.org/10. 1111/j.0045-3609.2005.00011.x

van Fleet, J. W. (2012). Scaling up corporate social investments in education: Five strategies that work (Global Views Policy Paper No. 2012-01). Washington, DC: Brookings Institution. Retrieved November 26, 2018, from https://www.brook ings.edu/wp-content/uploads/2016/06/05_corporate_investments_vanfleet.pdf

Verger, A. (2012). Framing and selling global education policy: The promotion of public-private partnerships for education in low-income contexts. Journal of Education Policy, 27(1), 109-130.

World Economic Forum. (2016). Alternative investment 2020: The future of capital for entrepreneurs and SMEs. Geneva, Switzerland: Author. Retrieved November 26, 2018, from http://www3.weforum.org/docs/WEF_AI_FUTURE.pdf 